\title{
COMPETENCES AND EDUCATIONAL POLICY- MAKING CONCERNING NATIONAL CURRICULA FOR SCHOOLS
}

\author{
Urve Läänemets \\ Estonian Academy of Music and Theatre, Estonia
}

\begin{abstract}
Competence-oriented approach for educational reforms, including national curriculum (NC) development, has been recommended both by the OECD and the European Commission since the beginning of the $21^{\text {st }}$ century. International assessment, especially PISA studies from 2003 onwards have also been using selected competences for comparing academic achievement of the 15-year- olds. The influence of the mentioned recommendations for NC development in Estonia has been analysed and the role of different types of knowledge has been highlighted.
\end{abstract}

Keywords: competences, educational reforms, educational policy-making, international comparative assessment, curriculum development, types of knowledge.

\section{Introduction}

The OECD yearbook 2018 „Education at a Glance” editorial starts with a philosophically strong statement: We are all born equal, but we are not born with the same opportunities. Some will be born to wealthy families, others will struggle to make ends meet. Some will grow up in an environment of conflict and turmoil, and will face the challenges of displacement and settling in a country that is not their own, others will benefit from a climate of social stability and prosperity their whole lives. Some will cope with a disability, struggling to learn to perform even basic tasks, while others may never realise the fortune of their good health.....Equity indeed is one of the fundamental values on which so many countries around the world have chosen to build their societies (OECD 2018:11).

However, educational systems and cultures, even if aspiring to provide the best and equal learning opportunities for their population, vary significantly, especially considering policy making for public education and development of national curricula under the present conditions of rapidly changing political, social and natural environments. The people of the $21^{\text {st }}$ century are expected to be flexible, adaptable and mobile in the global economy and have a potential to 
adequately meet upcoming challenges in their lives and societies. In addition, there are understandable aspirations to share global values and follow the recommendations offered by various international organisations, such as OECD, World Bank and EC, to name just a few.

The problem for studies has cropped due to different interpretations of the concept of competences. The aim of the research was to find out, how the concept of competences has been specified and developed within different international theoretical frameworks from the end of the $20^{\text {th }}$ century and during the first two decades of the 21st century and specify its potential for implementation in different contexts. The method used is documentary analysis. The main research questions were potential: how have these international recommendations been accepted and how they have influenced development of NC for general comprehensive schools in Estonia. The aim of this article is to point out the potential of external factors influencing national educational developments, both for individual learners and society.

\section{Global educational reform movement and competences}

The concept of competences people are expected to acquire by learning during their life - span has been popular from the end of the $20^{\text {th }}$ century as a functional means needed for achieving good or successful life (eg. Oates 1999, Rychen \& Salganik 2000, Canto-Sperber \& Dupuy 2001, Weinert 2001, et al). Presented competences have been so far differently interpreted, and Weinert revealed in 2001 already that there is no single use of the concept, neither any broadly accepted definition nor unifying theory (Weinert 2001). Still, Rychen and Salganik, aspiring for a holistic model of a competence opted for a functional approach to the concept and presented a definition they considered relevant for policy practice and research (Rychen-Salganik 2003: 42-43) as follows: (competence is) the ability to successfully meet complex demands in a particular context through the mobilisation of psychosocial prerequisites (including both cognitive and non-cognitive aspects). They highlight the value of functionality and recommend a clearly oriented approach for designing individual lifelong learning and taking career decisions. In addition, they provide as example an internal structure of a competence for cooperation, consisting of the following elements: knowledge, cognitive skills, practical skills, attitudes, emotions, values and ethics and motivation (ibid. 44). Understandably, different models with diverse structures can be designed and developed for specification, what a competence is, or can be. 
The results of using competences as a tool of policy-making became soon visible. The DeSeCo framework (Definition and Selection of Competencies: Theoretical and Conceptual Foundations), established in 2003 became a conceptual context for several international assessments, such as IALS (The International Adult Literacy Survey), PISA (The Programme for International Student Assessment), etc., but has also greatly influenced educational developments in the majority of European countries and beyond, especially considering general comprehensive schools, providing public education.

In 2018 the OECD PISA Global competence network was made available (see http://www.oecd.org), according to which global competence is the capacity to examine local, global and intercultural issues, to understand and appreciate the perspectives and world views of others, to engage in open, appropriate and effective interactions with people from different cultures, and to act for collective well-being and sustainable development. Eloquently worded good ideas as modern ideals for the $21^{\text {st }}$ century education need not be questioned, but it still requires clarification, if and why they should be taken as a foundation for comparative international assessment. Learning for the recommended competences still requires knowledge, skills, values and attitudes provided by education in all countries all over the world under their own circumstances. Understandably, knowledge is and remains the logical basis for development of skills, values and attitudes any learner or learning organisation must have before they become integrated as competences for acting in a specific field of everyday life.

The European parliament and the Council of the European Union concluded in Lisbon in March 2000 that a new European Framework, defining basic skills to be provided through lifelong learning as a key measure in Europe's response to globalisation within which the shift to knowledge based economies was expected with enhancement of the European dimension in education.

The Commission Communication "Making a European Area of Lifelong learning a Reality "and the subsequent Council Resolution of 27, 2002 on lifelong learning (LLL) specified the new basic skills as a priority. The need that LLL must cover learning from pre-school age to post-retirement age was stressed, which required a new approach for development of National Curricula (NC) for different levels of schooling. Skills became predominant over knowledge, although aspirations towards knowledge-based societies persisted. In May 2003, the Council adopted benchmarks (incl. reading literacy, early school leaving, completion of upper secondary education, etc.) as reference levels for specification of measurable improvement in education, which became closely 
linked to key competences. In 2003 the first PISA study was carried out in 30 partner countries and its results, (see http://www.oecd.org/education/school/ programmeforinternationalstudentassessmentpisa/34002454.pdf) turned fast out to be most influential on educational policy making in many countries.

When the report of the Council in 2005 showed that there has been no meaningful progress made in reducing the percentage of low achievers at the age of 15, there were several documents elaborated for vocational education and youth to be better supported for successful learning (e.g. the European Youth Pact 2005) with a special emphasis on the common set of core skills. Finally in 2006 , the agreed recommendations appeared with the aim to encourage and facilitate educational reforms in member states, expected to equip their citizens with competencies they need for remaining competitive on the global labour market. Accordingly, priority was given to Key Competencies Framework.

It was manifested with best intentions, as recommendations were expected to contribute to the development of high quality, future oriented education meeting the needs of European societies and supporting them at updating their initial education and training systems, so that they could offer all population, especially the young people, the means to develop key competences applicable in their future lives and for participation in LLL. This was a really meaningful statement, an attempt to improve and restore the position of European education. It was believed that these high aims cannot be sufficiently achieved by the Member States acting alone, and can therefore be better achieved at Community level, following common strategies, even the measures in accordance with the principle of subsidiarity as set in Article 5 of the Treaty were mentioned.

The following common eight key competencies were defined as a combination of knowledge, skills and attitudes appropriate to the context, needed by all individuals for personal fulfilment and development, active citizenship, social inclusion and employment.

The Reference Framework of 2006 set out eight key competencies: communication in the mother tongue; communication in foreign languages, mathematical competence and basic competences in science and technology; digital competence, learning to learn; social and civic competences; sense of initiative and entrepreneurship and cultural awareness and expression. Then and today the mentioned key competencies were considered equally important, as they all can contribute to a successful life in a knowledge-based society. It is evident, that these are often overlapping, supporting one another. Still, special attention has been focused on the fundamental basic skills of language, literacy, numeracy and in information and communication technologies (ICT) serving as foundations 
for all learning, as well as skills for learning to learn. There are also a number of meaningful integrating themes that are applied throughout the Framework: critical thinking, creativity, initiative, problem solving, risk assessment, decision taking, and constructive management of feelings, team-work, which deserve to be considered as goals, characterizing the desired competences, when planning and implementing local educational reforms.

In 2016 a Report was compiled on how these key competencies had been used in Member States. There were different approaches - from using copy pastemethod of including them into national documents, some countries used adopted versions of those competencies and some had implemented them with exclusion of some key competencies. The decisions taken in Member States were mostly informed decisions taken considering their educational traditions, school culture and socio-political circumstances.

A new and updated Framework of European key competencies was discussed and published in 2016-2017 with slight new specifications. In October 2018 a Webinar was organized on important issues: what countries and schools could do to help disadvantaged students and what to do with academic resilience. The main goal - desired improvement of academic achievement of students in Europe is still difficult to achieve and requires serious discussion, despite the everincreasing support offered by ICT.

\section{Key competences and curriculum development in Estonia}

Traditionally, Estonian educationists have been rather careful and specific about the knowledge students are expected to acquire at schools. There have been discussions, what to include as subjects with their specific content for learning into national curricula (NC) for general comprehensive schools since establishment of the statehood in 1918. The curriculum documents of different times have specified school subjects as recognised and functional fields of human experience, which deserve to be preserved and transferred as ethical values, knowledge and skills to the following generations with the aim to preserve the language, culture and ethnic identity. With regained independence in 1991 new approaches and wider contacts with educators all over the world started. Understandably, new ideas immediately became used, often focused on development of skills and making the process of learning more flexible, interesting, and also fun. Development of NC for schools became also more focused on acquisition of desired skills, making young people free and competitive. 
The NC of 1996 specified the following principles: equal opportunities for acquisition of education; humanism and democracy; patriotism and internationalism; development of all students; responsibility and active approach of learners; balance and integration of cultures; problem orientation; openness of the curriculum for schools and learners (NC 1996:1962). There were also four integrating themes specified: environment, traffic, choice of a future profession and ICT. Schools had to compile their own curricula and specify the content for leaning according to these guidelines.

Remarkably, there was also a short section on competences in the NC of 1996 without specification what they as concepts mean, only their potential as something useful and important uniting different school subjects, activities at school and extracurricular activities, also integrating values and skills was manifested. Three groups of competencies were mentioned, and namely: communicative competences, value competencies and competences related to activities, characterised as general competencies, including learning skills and skills for observation, making comparisons, reading, writing, listening and calculations (ibid; 1963). Understandably, schools had great difficulties when writing their own school curricula following such guidelines. The schools were trapped in new ideologies and values, which highlighted competitiveness, individual freedom, skills instead of knowledge and aspirations to increase motivation by fun and edutainment.

The next NC for Estonian general comprehensive schools appeared on 2002 with a new general introductory part specifying 16 general aims and a longer section dedicated to competences. The document was organised and presented as a legal act by articles and so, $\S 6$ introduced the need to develop competencies,§7 specified four general competences(competence to learn, competence to act, value competence and self-competence for development of one’s personality), §8 specified subject competences which were characterised by achieved academic results, eg.in maths, etc. subjects.

Finally, there were seven field competences in §9, which were expected to integrate general and subject competencies into some wider competences. Development of those was the responsibility of schools, and accordingly, teachers and school leaders were expected to support the following competences: competence of nature, social competence, competence for reflection and interaction, communicative competence, technology competence, cultural competence and mathematical competence. There were also four integrating themes mentioned to be used for development of competences, and namely: environment and sustainable development; professional career planning, info 
technology and media and safety. Short explanations of the mentioned competencies (NC 2002:872-873), unfortunately, did not create any system for meaningful school practice. As all subject syllabi remained the same, there was no connection between the introductory general part of the NC and the content of school subjects.

The present NC of 2012/2014 also uses the approach of competencies, and as there are two separate NC documents, one for compulsory schools and the other for upper secondary (called gymnasia), both have §4 specifying competences in a similar way as a complex of knowledge, skills, and approaches, which guarantees a person a capability to act creatively, flexibly and with initiative in a specific profession, or field. Both NCs differentiate between general and field competences and for compulsory schools there are also competencies expected to have been acquired by student by the end of different school stages (1-3, each of them covering 3 grades or classes). There are no more subject competences, but there are field competences to which close schools subjects (e.g. languages or sciences) are supposed to contribute There are 9 general competences: cultural and value competence; social and citizenship competence; competence for self-specification; competence for learning; communicative competence; math, science and technology competence; competence for entrepreneurship and digital competence. Again, development of competences has to be described in school curricula and teachers have to take responsibility for students' competences. Academic achievement of students in learning school subjects is supposed to support their development of competences, incl. general competences. Again, no structural or logical basis for implementation in school practice has been specified. As the new cycle of NC development has commenced, a decision has to be taken about different competences recommended recently both by OECD and European Commission.

\section{Discussion}

There have been different opinions and views expressed in academic circles. The Finnish analyst Pasi Sahlberg has called thee competence and accountability based and - led Global Education Reform Movement abbreviated as GERM, a virus, killing education (Sahlberg, 2011). Finnish PISA success of all the $21^{\text {st }}$ century studies has not been focused on outcomes, control, assessment industry requirements or competence orientation. They have followed a different ideology and the experience of their own school culture. It has been based on wisely selected and meaningful content of education and professionally sound 
organisation of process of studies by professional teachers, often specified as trustworthy intellectuals, leading students to learning with comprehension (Autio, 2017). Estonia has also been successful in recent PISA studies, which probably can still be explained by survival of the traditional achievement-oriented school culture, experienced, but elderly teachers, and students' good ICT skills. Three PISA competences, demonstrated so well by 15 year-olds tend to diminish by the end of upper secondary schools, so universities are worried.

It has to be admitted that we all interpret and comprehend the world around us differently, nevertheless knowledge and skills have become the currency of modern life, especially when thinking about shaping the modern digital turn. We also have to learn to become critical consumers of information (Schleicher, 2018, Schleicher, 2018a). True, education is no longer about reproducing what we know, but our knowledge has to become an informed understanding of the big picture of the world we live in. The amount of knowledge we possess, always characterises our relationship to multiple environments around us, showing how well we are informed about them (Wild, Hochberg, 2018). Any person, participating in formal, informal or non-formal learning acquires knowledge, skills and values, which establish a basis for human decision-making characterising the competence of how to act in different life situations, or solving problems. Different people use differently structured competences, based on different knowledge and experience for performing their everyday jobs or solving conflicts.

Accordingly, knowledge will always remain the basis for development of skills and further on - competences as meta-level capabilities uniting and integrating different cognitive and non-cognitive aspects. That is why W. Pinar has described education as a moral enterprise (Pinar, 2012). The same can be found in the works of Russian educationists, e.g. Chechlova, et al 2018, Guseva, 2017). Therefore, enhancing equity as a principle for educational policy-making, especially considering opportunities for learning and access to supportive environments for everybody, is definitely an essential component of improving quality of education outcomes (Sahlberg, 2018) leading to a more cohesive society.

The main finding was that competence based approach can be formally manifested as a common ground for establishing desired high and human aims, but their practical implementation for selection of the content for learning has proved difficult so far. The problem of balance between the common global, regional and diverse local values has persisted so far. There are also limitations to be considered, how far these recommended common competences, meant for life- 
long learning, can be implemented for different educational levels. Understandably, these preliminary findings deserve further discussion.

\section{Conclusion}

Informed educational policy-making for any society can be expected, if developments globally, regionally and locally are systematically monitored. There are both, external and internal factors influencing local educational developments. These must be carefully analysed and considered for potential implementation, considering local contexts and circumstances. A meaningful balance between global, regional and national aspirations has to be established for improvement of quality in education. This article has drawn attention to international recommendations, provided by OECD and the European Commission, and also analysed their impact on NC development based on Estonian example, other countries could learn from.

Practice has proved that all competences people develop, regardless of their age, are individual in character and consist of different components, obtained by highly diverse personal experience, and always contain knowledge accompanied by some moral judgement. As development of these competences in the processes of learning cannot be precisely prescribed, or assessed or measured in detail, so it is probably time to start thinking again more professionally about the content of learning and the knowledge it can provide for learning in different societies. The message "Back to real learning1" manifested in 2016 at the annual conference of IGIP/IEEE in Belfast (UK) sounds adequate to present times, bringing back to the focus and foreground the content of learning, according to which adequate methodologies and supportive learning environments can be designed and established, all together contributing to the desired aims for the $21^{\text {st }}$ century education.

\section{References}

Autio, T. (2017). Johtanto: kansainvälistyvä opetussuunitelmatutkimuskansallisen koulutuspolitiikkan ja opetussuunitelmareformien älyllisena ja poliiittisena ressusrsina. In: T. Autio, L. Hakala, T. Kujala (Eds.) Opetussuunitelmatutkimus. Keskustelunavauksia suomalaiseen koulun ja opetajan koulutukseen. Tampere University Press 2017, pp.17-58.

Canto-Sperber, M. \& Dupuy, J.P. (2001).Competencies for the good life and the good society. In: D.S. Rychen \& L .H. Salganik (Eds.), Defining and selecting key competencies (pp. 67-92). Göttingen, Germany: Hogrefe \& Huber. 
Chechlova, Z., Chechlovs, M., \& Gode, I. (2018). The methodology of the Development of Competency-based Approach Pedagogy. Society. Integration. Education. II. Proceedings of the International Scientific Conference May 25 $5^{\text {th }}-26^{\text {th }}$, 2018, pp. 93-102.

Education at a glance 2018. OECD Indicators (2018). OECD Yearbook.

Estonian National Curricula for general comprehensive schools of 1996, 2002 and 2012/2014.

Europen Key competences. Retrieved from http://mobilitycompetences.com/wpcontent/uploads/2016/10/The-8-key-competences-of-European-Union.pdf.

Guseva, V. (2017). The Pedagogical Tools for the Development of Compassion of the Primary School Children with Regard to their psychological Types. Society. Integration. Education. II. Proceedings of the International Scientific Conference May $26^{\text {th }}-27^{\text {th }}, 2017$, pp. 265-280.

Oates, T. (1999). Analysing and describing competence critical perspectives. Sudbury, England: Qualifications and Curriculum authority.

Pinar, W. F. (2012). The Character of Curriculum studies: Bildung, Currere, and the Recurring Questions of the Subject. New York, Palgrave, Macmillan.

Salganik, L.S. (2003). A holistic model of competence. In: D.S. Rychen \& L.H. Salganik (Eds.), Key Competencies for a Successful Life and a Well-Functioning Society (pp. 41-62). Göttingen, Germany: Hogrefe \&Huber.

Sahlberg, P. (2011). Finnish Lessons: What can the World Learn from Educational Change in Finland. New York: Peter Lang.

Sahlberg, P. (2018). FinnishED leadership. Four Big, Inexpensive Ideas to transform Education. Corwin. A Sage Publishing Company.

Schleicher, A. (2018). Shaping the Digital Turn. Synergie.\#06 Fachmagazin Universität Hamburg, pp.10-15.

Schleicher, A. (2018a). World Class. How to build a $21^{\text {st }}$ century school system. OECD.

Weinert, F. E. (2001). Concept of competence: A conceptual clarification. In D.S. Rychen \&l.H. Salganik (Eds.), Defining and selecting key competencies (pp 45-65). Göttingen, Germany: Hogrefe \&Huber.

Wild, R. \& Hochberg, J. (2018). Studieren in der Zukunft: Wird der Digital Turn zum Individual Turn? Synergie \#06 Fachmagazin Universität Hamburg, pp. 64-67. 